(RESEARCH ARTICLE)

\title{
In-vitro interaction of daminozide with some amino acids
}

\author{
Dağ Şeker ${ }^{1, *}$ and Dere Egemen ${ }^{2}$ \\ ${ }^{1}$ Sivas Cumhuriyet University, Faculty of Science, Department of Biology SiVAS. \\ ${ }^{2}$ Uludag University, Faculty of Arts and Sciences, Department of Biology BURSA.
}

Publication history: Received on 06 January 2020; revised on 13 January 2020; accepted on 22 January 2020

Article DOI: https://doi.org/10.30574/wjarr.2020.5.1.0007

\begin{abstract}
In this study, the interaction of plant growth regulatory substance daminozide with alanine, arginine, glycine, glutamic acid, histidine, isoleucine, methionine, phenylalanine, threonine, tryptophan, tyrosine and valine has been investigated by thin-layer chromatography. In the experiment 100, 200 and 400 ppm doses of daminozide has been used. At the end of experiments with or without for 24 hours, in the Retention factor (Rf ) value, according to standard amino acids values, some increasing or decreasing values have been observed. Moreover some alterations in maximum absorption peaks on the spectrums taken from thin-layer cromotgraphy samples have been observed. It has been observed that there were some changes in amino acids with different daminozide doses. The obtained results show that daminozide either will be able to bound to amino acids or form new copounds under in-vitro conditions.
\end{abstract}

Keywords: Daminozide; Amino Acids; Thin-layer cromotgraphy

\section{Introduction}

Today, rapidly increasing world population brings many problems. Adequate and balanced nutrition problem is among the first conceivable problems. The world as a solution to this problem genetically modified food production, uses pesticides and hormones in order to obtain more and more quality products from existing agricultural areas. Nowadays, depending on the increase in crops, 10-15 pesticides per year in vegetables and fruits can be considered normal. More than one active ingredient can be used even in one application. These agents have been designed specifically to kill weeds and insect pests in agriculture. The annual world pesticide use was 3.8 million tons, which is 59 thousand tons as of 2017 year-end rate in Turkey [1]. Indeed, the use of these substances results in substantial economical benefits. However, in the soil, water remains intact on fruits vegetables for a long time and pesticides reaching humans through the food chain have allergic, carcinogenic, mutagenic and teratogenic effects [2-5].

After occurunce of these harmful effects of pesticides restrictions have been made on the use of pesticides to protect human health and the environment. As a result, pesticides that are not harmful to human health and are effective against pests are being studied in the environment. Daminozide is one of the herbicides that have been used frequently in our country in recent years. Daminozide (succinic acid 2, 2-dimethyl hydrazide, tradename is Alar) is a plant-growth regulator and has been registered since 1963. Nectarines, peaches, pears, Concord grapes, tomatoes and peanuts etc. were used Daminozide in fruit trees increases fruit maturity, fruit hardness and colouration. It delays fruit fall before harvest. Improves market quality of fruit during harvest and storage. Daminozide modifies branch and stem length in ornamental plants [6-9].

In studies which conducted on apples treated with daminozide, the most important metabolites that can show carcinogenic effects are found to be anymmetrical 1,1-dimethylhydrazine (UDMH) and Dimethylnitrosamine (DMN) $[10,11]$. After these findings, studies on plants and mammals were accelerated and at the same time, the use of fruit and

\footnotetext{
* Corresponding author

E-mail address: sdag@cumhuriyet.edu.tr
} 
vegetable cultivation was banned in many developed countries. The World Environmental Protection Organization (EPA) issued a declaration in August 1985, temporarily banning the use of daminozide. However, the manufacturer reported that the EPA's research did not agree with their work in their laboratory. The EPA then issued a statement in January 1986, annulling the decision prohibiting the use of daminozide until sufficient information and experiments were carried out [11-14].

Daminozid in the cultivation of ornamental plants and which is still used in many countries as an agricultural herbicide, were launched in the 1980s in Turkey.

In this study, it is aimed to investigate effects of daminozide on some amino acids by Thin Layer Chromatography (TLC) method in order to reveal the effects of daminozide on some amino acids and to clarify the studies on this subject, especially the discussions on changes in enzyme structure and enzyme activation.

\section{Material and methods}

In our study, $25 \mathrm{~g}$ of silica gel G-60 was used for five glass plates, $20 \mathrm{x} 20 \mathrm{~cm}$ in dimensions and $4 \mathrm{~mm}$ in depth. Silica gel was homogenated in $60 \mathrm{ml}$ of double distilled water and spread onto glass plate, $0.25 \mathrm{~mm}$ in depth by a spreader. Plates were prepared by activating them at room temperature for 24 hours. The amino acids employed in this experiment (alanine, arginine, glycine, glutamic acid, histidine, isoleucine, methionine, phenylalanine, threonine, tryptophan, tyrosine and valine) were prepared at a concentration of $10 \mathrm{mg} / \mathrm{mL}$ while the concentration values of the daminozide were prepared as 100, 200 and $400 \mathrm{ppm}$. These doses were used according to [15]. Each concentration of daminozide was mixed with every amino acid (1:1) and non-incubated, daminozide-amino acid mixtures and mixtures incubated for 24 hours were used in the experiment. Incubation was at room temperature. Three (3) $\mu \mathrm{L}$ of amino acids, daminozide and mixtures were individually applied to the double plates. For running process, plates were put in a mixture prepared with EtOH (96\%) and double distilled water at a proportion of 70:30 for 4.5 hours. At the end of this period, the running levels of the solvent were marked and plates were dried. The double plates contained the same sample. Which one of the plates, However was coloured with ninhidrine, the other plate was recovered from the marked place at a $1.0 \mathrm{~cm}$ in diameter. After a five minutes centrifugation of the scraped parts with three $\mathrm{mL}$ of $0.1 \mathrm{~N} \mathrm{HCI}$ at $3000 \mathrm{rpm}$, supernatant was read out at 200-300 $\mathrm{nm}$ wave length using the Shimadzu 160 UV spectrophotometer [15].

\subsection{Evaluation of data}

For calculating the Rf values of the samples, the experiments were repeated 6 (min.) to 10 times (max.). After TLC, the Rf values of the samples were calculated according to the following relation [15].

$\mathrm{Rf}=$ The distance moved by solute from origin / the distance moved by solvent from origin $\mathrm{x} 100$.

The results were loaded into SPSS (Ver. 14.0) program and variance analysis, Tukey Test, and error level (p) were taken as 0.05 .

\section{Results}

For all the experimental studying periods, Rf values of the amino acids and mixtures on the plates stained with ninhidrine after TLC, were calculated. The obtained results and the statistical data applied to them are given in Table 1. The spectra of the recovered samples taken from the parallel plates were calculated and maximum absorbance and wave length values are shown in Table 2.

The Rf value of alanine was 75.95, and compared with the Rf value of the incubated and non-incubated mixtures of all three doses of daminozide, these values increased were significantly and the increases were statistically significant Table 1.

The maximum absorption of Alanine at the wavelength of $201 \mathrm{~nm}$ was significantly lowered in the non-incubated mixtures at all 3 doses studied Table 2. As a result of the 24-hour incubation, the maximum absorbances were 100 and $400 \mathrm{ppm}$ at $201.6 \mathrm{~nm}$ and $200 \mathrm{ppm}$ at $202.1 \mathrm{~nm}$ Table 2.

The Rf value of Arginine was found to be 14.58. For each dose, differences between the incubated and non-incubated mixtures were found to be insignificant Table 1. It was found that the value obtained after 24 hours incubation at 400 ppm dose was significant compared to the value obtained from the incubation of 100 and 200 ppm doses Table 1. 
The maximum absorbance of arginine in the absorbed spectra was determined as $201.4 \mathrm{~nm}$. It was observed that there was no shift in this wavelength at each dose studied Table 2. However, small fluctuations are observed in the maximum absorbances detected at the $201.4 \mathrm{~nm}$ branch length Table 2 .

Rf value of phenylalanine was determined as 94.20. In the studies with phenylalanine, the highest Rf value was calculated as 95.19 at the 100 ppm dose incubated for 24 hours and the lowest Rf value was 87.90 at the 200 ppm dose not incubated. Rf values of the incubated and non-incubated samples were found to be insignificant in comparison between doses Table 1.

The maximum absorption in the spectral spectrum of phenylalanine was determined at $205 \mathrm{~nm}$. This wavelength only shifted to $206.2 \mathrm{~nm}$ at a dose of $400 \mathrm{ppm}$, both incubated and non-incubated, but It was the same in other doses as phenylalanine. The maximum absorbance at all doses studied was less than the absorption of phenylalanine $(1,172)$ Table 2.

The Rf value of glycine was determined to be 72.7. This value is similar to the $72.93 \mathrm{Rf}$ value of daminozide. In the study with glycine, the Rf value of $100 \mathrm{ppm}$ non-incubated mixture was found to be significant compared to the value of glycine and the incubated mixture. The values of nonincubated $200 \mathrm{ppm}$ and $400 \mathrm{ppm}$ doses are insignificant compared to glycine. The Rf values of the incubated mixtures are important in all 3 doses according to the glycine value Table 1 . While the maximum value of the measured spectrum of glycine was $210 \mathrm{~nm}$, the spectrum and absorbance values were different for all incubated and non-incubated doses Table 2.

Rf value of glutamic acid was determined as 84.10. This value was greater than the Rf values calculated in both unincubated and incubated mixtures Table 1 . When the inter-dose value of the interaction of glutamic acid with daminozide was evaluated statistically, there was no difference between the Rf values obtained without incubation, but the Rf values after 24 hours incubation showed that the 200 ppm dose was important among the other two doses Table 1.

The maximum absorbance in the spectra of glutamic acid was $208.8 \mathrm{~nm}$. The maximum absorbances of all samples interacted with daminozide shifted to $202 \mathrm{~nm}$ wavelength Table 2.

While the Rf value of histidine was determined as 62.49, the calculated Rf values of all 100,200 and 400 ppm test samples were determined at the same level as the histidine value. The differences between the values of the incubated and unincubated samples were statistically insignificant Table 1.

The spectra of the histidine recovered from TLC by scraping was determined at $210.4 \mathrm{~nm}$ at maximum. There were no changes at the maximum absorbance wave lenght of incubated and non-incubated spectrums of histidine, while some absorbance differences were recorded Table 2.

The Rf value of isoleucine was determined as 82.08. Rf values calculated after 24 hours incubation of daminozide every 3 doses are higher than isoleucine. However, the Rf values of the non-incubated doses were lower than the Rf value of isoleucine. When the Rf values of the unincubated and incubated mixtures were compared, statistically significant differences were found in all 3 daminozide doses Table 1.

In the absorbed spectrum of isoleucine, maximum absorbance was recorded at $201 \mathrm{~nm}$ wavelength. The maximum absorption wavelengths of the non-incubated and incubated samples were higher than the wavelength of isoleucine Table 2.

The Rf value of methionine amino acid was determined as 84.78. Both incubated and non-incubated all three doses, Rf values were higher than in methionine Rf value. The difference between Rf values of the 200 ppm samples incubated and non-incubation and the Rf values of methionine were insignificant whereas the difference between the values of the other doses were significant Table 1.

The maximum spectral value of methionine showed maximum absorbance at $205.6 \mathrm{~nm}$ wavelength, while the maximum peak wavelengths and absorbances of all incubated and non-incubated doses changed Table 2.

The Rf value of threonine was 88.77. The Rf values of each 3 doses of the incubated and non-incubated mixtures were lower than the Rf value of threonine. This decrease in Rf values is statistically significant Table 1. 
Table 1 Rf values depending on doses of incubated and non-incubated mixtures

\begin{tabular}{|c|c|c|c|c|c|}
\hline $\begin{array}{l}\text { Amino } \\
\text { acids }\end{array}$ & $\begin{array}{l}\text { Daminozide } \\
\text { Doses } \\
\text { (ppm) }\end{array}$ & $\begin{array}{l}\text { Amino Acid } \\
\text { Mean } \pm \text { S.E.* }\end{array}$ & $\begin{array}{l}\text { Daminozide } \\
\text { Mean } \pm \text { S.E* }\end{array}$ & $\begin{array}{l}\text { Non-incubated Mix } \\
\text { Mean } \pm \text { S. E.* }\end{array}$ & $\begin{array}{l}24 \text { hours incubated Mix } \\
\text { Mean } \pm \text { S. E.* }\end{array}$ \\
\hline \multirow[t]{3}{*}{ Ala } & 100 & $75.95 \pm 0.70 \mathrm{a}$ & $72.93 \pm 1.19 \mathrm{~b}$ & $91.24 \pm 0.80 \mathrm{cx}$ & $82.49 \pm 0.48 \mathrm{dx}$ \\
\hline & 200 & & & $84.78 \pm 0.85$ cy & $79.16 \pm 0.00 \mathrm{dxy}$ \\
\hline & 400 & & & $84.99 \pm 1.01$ cy & $78.33 \pm 1.31 \mathrm{dy}$ \\
\hline \multirow[t]{3}{*}{ Arg } & 100 & $14.58 \pm 0.24 \mathrm{a}$ & $72.93 \pm 1.19 b$ & $13.52 \pm 1.02 \mathrm{ax}$ & $12.91 \pm 0.41 \mathrm{ax}$ \\
\hline & 200 & & & $12.91 \pm 0.10 \mathrm{ax}$ & $12.50 \pm 0.00 \mathrm{ax}$ \\
\hline & 400 & & & $14.79 \pm 0.21 \mathrm{ax}$ & $15.40 \pm 0.40$ ay \\
\hline \multirow[t]{3}{*}{ Phe } & 100 & $94.20 \pm 0.75 \mathrm{a}$ & $72.93 \pm 1.19 b$ & $91.66 \pm 0.00 \mathrm{cx}$ & $95.19 \pm 0.39 \mathrm{ax}$ \\
\hline & 200 & & & $87.90 \pm 0.87 \mathrm{cx}$ & $93.31 \pm 1.47 \mathrm{ax}$ \\
\hline & 400 & & & $91.86 \pm 1.90 \mathrm{ax}$ & $94.78 \pm 1.04 \mathrm{ax}$ \\
\hline \multirow[t]{3}{*}{ Gly } & 100 & $72.70 \pm 0.86 \mathrm{a}$ & $72.93 \pm 1.19 \mathrm{a}$ & $79.85 \pm 1.22 \mathrm{bx}$ & $90.49 \pm 1.90 \mathrm{cx}$ \\
\hline & 200 & & & $74.37 \pm 1.19$ ay & $83.33 \pm 1.70$ by \\
\hline & 400 & & & $71.85 \pm 1.05$ ay & $84.11 \pm 1.99$ by \\
\hline \multirow[t]{3}{*}{ Glu } & 100 & $84.10 \pm 0.59 \mathrm{a}$ & $72.93 \pm 1.19 b$ & $81.00 \pm 1.00 \mathrm{cx}$ & $70.90 \pm 1.30 \mathrm{bx}$ \\
\hline & 200 & & & $78.20 \pm 0.68 \mathrm{cx}$ & $62.85 \pm 0.95 \mathrm{dy}$ \\
\hline & 400 & & & $79.80 \pm 0.94 \mathrm{cx}$ & $72.17 \pm 1.14 \mathrm{bx}$ \\
\hline \multirow[t]{3}{*}{ His } & 100 & $62.49 \pm 1.70 \mathrm{ac}$ & $72.93 \pm 1.19 b$ & $67.49 \pm 1.47 \mathrm{ax}$ & $60.40 \pm 1.21 \mathrm{cx}$ \\
\hline & 200 & & & $58.30 \pm 2.42 \mathrm{ax}$ & $59.97 \pm 1.02 \mathrm{ax}$ \\
\hline & 400 & & & $63.32 \pm 1.02 \mathrm{ax}$ & $63.54 \pm 1.04$ ay \\
\hline \multirow[t]{3}{*}{ İle } & 100 & $82.08 \pm 0.72 \mathrm{a}$ & $72.93 \pm 1.19 b$ & $77.08 \pm 1.20 \mathrm{cx}$ & $90.62 \pm 1.04 \mathrm{dx}$ \\
\hline & 200 & & & $73.53 \pm 0.99 \mathrm{bx}$ & $88.54 \pm 1.04 \mathrm{cx}$ \\
\hline & 400 & & & $78.23 \pm 1.04 \mathrm{cy}$ & $91.03 \pm 0.39 \mathrm{dx}$ \\
\hline \multirow[t]{3}{*}{ Met } & 100 & $84.78 \pm 1.37 \mathrm{a}$ & $72.93 \pm 1.19 b$ & $92.91 \pm 0.72 \mathrm{cx}$ & $88.75 \pm 0.72 \mathrm{dx}$ \\
\hline & 200 & & & $87.50 \pm 1.02$ ay & $85.60 \pm 0.86$ ay \\
\hline & 400 & & & $88.52 \pm 1.02$ cy & $88.33 \pm 0.58 \mathrm{cx}$ \\
\hline \multirow[t]{3}{*}{ Thr } & 100 & $88.77 \pm 3.39$ & $72.93 \pm 1.19 b$ & $73.95 \pm 1.05 \mathrm{bx}$ & $76.04 \pm 1.04 \mathrm{bx}$ \\
\hline & 200 & & & $69.78 \pm 1.99 \mathrm{bx}$ & $69.35 \pm 0.97$ by \\
\hline & 400 & & & $74.57 \pm 1.38 \mathrm{bx}$ & $76.02 \pm 1.02 \mathrm{bx}$ \\
\hline \multirow[t]{3}{*}{$\operatorname{Trp}$} & 100 & $94.58 \pm 0.99 \mathrm{a}$ & $72.93 \pm 1.19 b$ & $92.70 \pm 1.03 \mathrm{ax}$ & $90.62 \pm 1.04 \mathrm{cx}$ \\
\hline & 200 & & & $88.31 \pm 0.97 \mathrm{cy}$ & $88.73 \pm 1.69 \mathrm{cx}$ \\
\hline & 400 & & & $92.69 \pm 1.03$ acxy & $91.66 \pm 0.00 \mathrm{cx}$ \\
\hline \multirow[t]{3}{*}{ Tyr } & 100 & $98.14 \pm 1.07 \mathrm{a}$ & $72.93 \pm 1.19 b$ & $99.16 \pm 0.48 \mathrm{ax}$ & $89.58 \pm 2.68 \mathrm{cx}$ \\
\hline & 200 & & & $97.08 \pm 0.41$ ay & $88.53 \pm 1.99 \mathrm{cx}$ \\
\hline & 400 & & & $95.83 \pm 0.00 \mathrm{az}$ & $81.23 \pm 1.37 \mathrm{cx}$ \\
\hline \multirow[t]{3}{*}{ Val } & 100 & $76.87 \pm 0.62 \mathrm{a}$ & $72.93 \pm 1.19 b$ & $87.07 \pm 0.42 \mathrm{cx}$ & $83.33 \pm 0.00 \mathrm{dxy}$ \\
\hline & 200 & & & $85.40 \pm 1.21 \mathrm{cx}$ & $80.19 \pm 1.98$ ay \\
\hline & 400 & & & $87.50 \pm 0.00 \mathrm{cx}$ & $85.40 \pm 1.21 \mathrm{cx}$ \\
\hline
\end{tabular}


Table 2 Maximum absorbance and wavelengths of the samples recovered from TLC by scrapings.

\begin{tabular}{|c|c|c|c|c|c|c|c|}
\hline \multirow{2}{*}{$\begin{array}{l}\text { Amino } \\
\text { Acids }\end{array}$} & \multirow{2}{*}{$\begin{array}{l}\text { Daminozide } \\
\text { Doses (ppm) }\end{array}$} & \multicolumn{2}{|c|}{ Amino Acids } & \multicolumn{2}{|c|}{ Non-incubated Mix } & \multicolumn{2}{|c|}{24 hours incubated Mix } \\
\hline & & $\lambda(\mathrm{nm})$ & Max.Abs. & $\lambda(\mathrm{nm})$ & Max.Abs & $\lambda(\mathrm{nm})$ & Max.Abs \\
\hline \multirow[t]{3}{*}{ Ala } & 100 & & & 207.3 & 0.004 & 201.6 & 0.369 \\
\hline & 200 & 201.0 & 0.048 & 202.3 & 0.004 & 202.1 & 0.253 \\
\hline & 400 & & & 206.2 & 0.004 & 201.6 & 0.228 \\
\hline \multirow[t]{3}{*}{ Arg } & 100 & & & 201.4 & 0.291 & 201.4 & 0.362 \\
\hline & 200 & 201.4 & 0.713 & 201.4 & 0.270 & 201.4 & 0.304 \\
\hline & 400 & & & 201.4 & 0.388 & 201.4 & 0.474 \\
\hline \multirow[t]{3}{*}{ Phe } & 100 & 205.0 & & 205.0 & 0.713 & 205.0 & 0.665 \\
\hline & 200 & & 1.172 & 205.0 & 0.690 & 205.0 & 0.432 \\
\hline & 400 & & & 206.2 & 1.044 & 206.2 & 1.123 \\
\hline \multirow[t]{3}{*}{ Gly } & 100 & & & 205.0 & 0.028 & 201.0 & 0.062 \\
\hline & 200 & 210.0 & 0.052 & 201.0 & 0.055 & 201.0 & 0.072 \\
\hline & 400 & & & 201.5 & 0.044 & 201.0 & 0.079 \\
\hline \multirow[t]{3}{*}{ Glu } & 100 & & & 202.0 & 0.068 & 202.0 & 0.074 \\
\hline & 200 & 208.8 & 0.031 & 202.0 & 0.044 & 202.0 & 0.082 \\
\hline & 400 & & & 202.0 & 0.056 & 202.0 & 0.082 \\
\hline \multirow[t]{3}{*}{ His } & 100 & & & 210.5 & 0.426 & 210.4 & 0.966 \\
\hline & 200 & 210.4 & 0.941 & 210.4 & 0.746 & 210.4 & 0.905 \\
\hline & 400 & & & 210.3 & 0.656 & 210.4 & 1.100 \\
\hline \multirow[t]{3}{*}{ İle } & 100 & & & 210.6 & 0.025 & 204.0 & 0.046 \\
\hline & 200 & 201.0 & 0.072 & 210.6 & 0.023 & 202.0 & 0.044 \\
\hline & 400 & & & 210.6 & 0.026 & 204.0 & 0.084 \\
\hline \multirow[t]{3}{*}{ Met } & 100 & & & 202.7 & 0.319 & 202.4 & 0.877 \\
\hline & 200 & 205.6 & 1.331 & 205.0 & 0.200 & 202.5 & 0.773 \\
\hline & 400 & & & 203.7 & 0.326 & 202.9 & 1.051 \\
\hline \multirow[t]{3}{*}{ Thr } & 100 & & & 208.0 & 0.024 & 201.0 & 0.175 \\
\hline & 200 & 207.1 & 0.074 & 209.3 & 0.019 & 201.0 & 0.177 \\
\hline & 400 & & & 211.2 & 0.021 & 201.0 & 0.171 \\
\hline \multirow[t]{6}{*}{ Trp } & 100 & & & 217.3 & 0.517 & 218.4 & 0.515 \\
\hline & & & & 279.4 & 0.086 & 278.9 & 0.079 \\
\hline & 200 & 217.2 & 0.440 & 218.1 & 0.572 & 218.0 & 0.570 \\
\hline & & 278.0 & 0.080 & 277.5 & 0.089 & 278.1 & 0.102 \\
\hline & 400 & & & 217.9 & 0.447 & 218.0 & 0.464 \\
\hline & & & & 279.4 & 0.068 & 278.7 & 0.092 \\
\hline \multirow[t]{6}{*}{ Try } & 100 & & & 201.4 & 1.055 & 202.4 & 1.507 \\
\hline & & & & 223.7 & 1.010 & 223.6 & 1.764 \\
\hline & 200 & 202.4 & 1.304 & 201.8 & 1.241 & 202.4 & 1.432 \\
\hline & & 223.7 & 1.464 & 224.1 & 1.247 & 223.6 & 1.641 \\
\hline & 400 & & & 201.4 & 0.986 & 202.5 & 1.502 \\
\hline & & & & 223.7 & 0.901 & 223.4 & 1.749 \\
\hline \multirow[t]{3}{*}{ Val } & 100 & & & 207.6 & 0.041 & 208.6 & 0.054 \\
\hline & 200 & 201.0 & 0.074 & 208.0 & 0.040 & 202.0 & 0.067 \\
\hline & 400 & & & 208.0 & 0.027 & 207.0 & 0.043 \\
\hline
\end{tabular}


While the maximum absorption wavelength of threonin was $207.1 \mathrm{~nm}$, these values increased in the non-incubated group in the experimental groups, but lower than the maximum wavelength of threonin in the incubated group. Absorption values were different in both groups Table 2.

The Rf value of tryptophan amino acid was measured as 94.68. The Rf values of all the doses in the experimental group, the incubated and non-incubated samples were lower than the value of tryptophan. The difference between the Rf values of the non-incubated $200 \mathrm{ppm}$ dose and each of the 3 incubated doses was significant with the Rf value of tryptophan Table 1.

In the drawn spectrum of tryptophan it gave maximum peaks of 217.2 and 278.0 at two different wavelengths. Likewise, maximum absorption peaks at two different wavelengths were measured in all samples of the experimental group. Slight variations in both wavelengths and absorption values were detected Table 2.

The Rf value of tyrosine amino acid was found to be 98.14, while the Rf values of the nonincubated doses were close to the tyrosine, and the difference between them was insignificant. However, the values of all incubated doses were lower than those of tyrosine, and the difference was statistically significant Table 1.

In the spectrum of tyrosine, the maximum absorption values were obtained at two different wavelengths (202.4 and $223.7 \mathrm{~nm}$ ), just like the amino acid tryptophan. Likewise, maximum absorption values at two different wavelengths were measured in all samples of the experimental group. Slight variations in both wavelengths and absorption values were detected Table 2.

The value of valine was 76.87. The values of the incubated and non-incubated samples were higher than the Rf value of pure valine. While the difference between the Rf value and valine value of the 200 ppm dose incubated for only 24 hours was insignificant, the differences with all other samples were significant Table 1.

The spectra of valine the maximum absorbance wavelength was $201.0 \mathrm{~nm}$, while the maximum absorbance wavelengths of the samples were greater Table 2 .

\section{Discussion}

The beginning of the studies to increase the production in agriculture goes back to ancient times. The use of chemicals for the first time in combating pests coincides with the end of the 19 th century. During this period, the use of copperacetatarsenite (Paris green) has been quite successful against cotton pests. The use of dichloro-diphenyl trichloroethane (DDT) as an insecticide during the Second World War, the presence of 2,4-Dichlorophenoxy acetic acid (2,4-D) and its use as herbicides are described as important steps in their own period [16, 17]. Later, the use of hormones, plant growth regulators, led to a new era in agriculture. The widespread and uncontrolled use of these chemicals brought about environmental problems. Therefore, many researchers have started their studies in this direction [11, 18-24].

In this study, in vitro effects of daminozide, which is used as both herbicide and growth regulator, on amino acids were investigated. The decrease and increase in Rf values of the samples incubated and not in our experiments, the shifts in the maximum absorption of some amino acids suggest that daminozide may interact with amino acids. The importance of this situation in terms of human health can not be ignored. Because the changes in the structure and function of proteins that have important functions in metabolism and their building blocks and amino acids are exposed to interactions with pesticides will cause the disorders in the organism. Although in-vivo studies and in-vitro studies differ from each other, the fact that daminozide has been converted to UDMH released as a hydrolysis product for living systems and has been shown to be 26 times more toxic than daminozide supports our opinion that it may affect amino acids in-vivo [25].

Pesticides that enter living systems in various ways usually interact with proteins in two ways. The first is the hydrophobic interactions that may occur between aromatic amino acids on proteins and aromatic aromatic rings in pesticides. Secondly, the binding between negative and positive groups of amino acids and charged groups of pesticides. Even if proteins try to protect themselves from these toxic effects with their three-dimensional structures, interactions that may occur due to the toxic effects of pesticides can change the structure and function of proteins. These changes result in carcinogenic and non-carcinogenic dermatologic, neurological diseases [26, 27].

Influence of amino acids in this way can lead to disturbances in important functions of proteins. One of these important functions is DNA interaction with histone proteins. The fact that the amino acids here are affected also suggests that 
DNA may be affected. The fact that DNA was methylated in a study explains this idea [27, 28]. Sagelsdorrf et. al., in his research also in mice lung tumor, alveolar bronchial gland tissue tumor formation has been reported [28].

In our study, it was observed that the values of glycine, alanine, valine and isoleucine, which are neutral aliphatic amino acids are effeced by daminozide which incubated for 24 hours, increased by the effect of daminozide. It is noteworthy that these amino acids (except glycine) are non-polar amino acids. Therefore, it may be thought that the value of these non-polar amino acids in their interactions with daminozide may be increased due to the increase in solubility in TLC medium (water + ethanol). In the aromatic amino acids, phenyl alanine, tryptophan and tyrosine decreased the calculated value without incubating only with phenyl alanine, while tryptophan and tyrosine decreased after 24 hours of incubation. We think that these amino acids with aromatic structure can bond with daminozide to form new molecules. The fact that aromatic molecules easily react with groups such as $\mathrm{COOH}, \mathrm{CH} 3, \mathrm{OH}$ supports our opinion [29].

In our findings, we also observed acidic and basic amino acids. Glutamic acid, one of the acidic amino acids, decreased its value in all three doses studied, while histidine and arginine, which are basic amino acids, were affected in all three doses of daminozide. The reason for this is the hydrazine group in the structure of daminozide. These groups are capable of repelling electrons due to their hyper conjugation effect. Thus, the basic amino acids histidine and arginine are unaffected, while the acidic amino acid glutamic acid may be affected. However, considering the bonding properties of the carbonyl groups in the daminozide, the amino acids we studied may have been affected by these points.

This effect of amino acids in living systems will also affect enzymes that play an important role in biological reactions. The presence of the affected amino acids in the enzyme active center will cause the lose enzyme activity, disrupt its three-dimensional structure, and will cause different diseases in metabolism. In a study conducted in mice, the influence of daminozide on Alkaline Phosphatase activity [30], the activity of chickens glutathione-S-transferase (GST) and microsomal nitrosodimethylamine demethylase activites, the activity of inhibited GST activity was increased [31]. The change in the activities of the enzymes supports our suggestions.

Important amino acids, especially essential for mammals, may be affected by daminozide, leading to significant metabolic damage caused by deficiencies of these amino acids. The metabolites of daminozide, UDMH and DMN, have been shown to be capable of binding to biological substances, and these substances have been shown to be genotoxic, mutagenic and teratogenic [11, 27] [32-33].

\section{Conclusion}

This research was carried out in-vitro conditions. We need to consider that daminozide or UDMH or DMN may also affect amino acids in vivo. Daminozide is still used in ornamental plant cultivation and fruit growing. The emergence of hydrolysis products UDMH and DMN due to the easy dissolution of daminozide in water should be considered as inevitable for both environmental pollution and negative effects on living organisms in this environment [34, 35].

\section{Compliance with ethical standards}

\section{Acknowledgments}

There are no acknowledgements to mention.

\section{Disclosure of conflict of interest}

The author declares no conflict of interest.

\section{References}

[1] Turkish Statistical Institute. (2017).

[2] Sinha VS and Kumar N. (2014). Assessment of mito-inhibitory and genotoxic effects of two organophosphate pesticides in the root tip cells of Allium cepa L. Ann Plant Sci, 3, 699-703.

[3] Bianchi J, Mantovani MS and Marin-Morales MA. (2015). Analysis of the genotoxic potential of low concentrations of malathion on the Allium cepa L. cells and rat hepatoma tissue culture. J Environ Sci (China), 36, 102-111.

[4] Datta S, Singh J and Singh S. (2018). Assessment of genotoxic effects of pesticide and vermicompost treated soil with Allium cepa test. Sustainable Environment Research. 28(4), 171-178. 
[5] Verma S and Srivastava A. (2018). Morphotoxicity and cytogenotoxicity of pendimethalin in the test plant Allium cepa L. - A biomarker based study. Chemosphere. 206, 248-254.

[6] Thompson SA, Weston GD and Thomas TH. (1984). The effects of daminozide and under-soil heating on the growth of radish. Elsver Science Publishers B.V. Amsterdam-Printer in the Neherlands Sci. Harticul. 23, $151-158$.

[7] Pobudkiewicz A and Treder J. (2006). Effect of flurprimidol and daminozide on growth and flowering of oriental lily "Mona Lisa". Scientia Horticulturae, 110, 328-333.

[8] Hashemabadi D, Lipaei SR, Shadparvar V, Zarchini M and Kavaiani B. (2012). The effect of cycocel and daminozide on some growth and flowering characteristics of Calendula officinalis L., an ornamental and medicine plant. Journal of Medicinal Plants Research, 6(9), 1752-177.

[9] Salachna P and Zawadzińska A. (2017). Effect of daminozide and flurprimidol on growth, flowering and bulb yield of Eucomis autumnalis (Mill.) Chitt. Folia Horticulturae, 29, 33-38.

[10] Saxton LW, Steinbrecher K and Gunderson E. (1989). Result of a survey fort the presence of daminozide and unsymmetrical dimethylhyrazine in food. J.Agric. Food. Chem. 37, 570-573.

[11] US Environmental Protection Agency Oct. 8. (1992). Daminozide: Notice of final determination for noon-food uses and termination of the daminozide Special Review. Federal Register, 57 (196), 4643-44.

[12] S Environmental Protection Agency. (1986). Chemical fact sheet for daminozide (Faxt Sheet Number 26). US EPA, Washington, DC.

[13] US Environmental Protection Agency. (1989). Pesticide tolerance for Daminozide Federal Register 54(27), 63926.

[14] Uniroyal. (1993). Database on daminozide. Healt and Regulatory Compliance Dept., Uniroyal Corp., Middlebury, CT.

[15] Stahl E. (1965). Thin layer chromatography a laboratory handbook. Academic press. Inc. Publishers 111 Fifth Avenue, New York.

[16] Uygun N. (1976). Negative effects of agricultural pesticides. Seminar on the use of pesticides. METU-Gaziantep Campus Publication, 1, 63-80.

[17] Meister RT. (ed). (1992). Farm. Chemicals Handbook'92. Meister Publishing Company.

[18] British Crop Protection Council. (1983). The Pesticide Manual: A World Cpmpedium. 7th ed. Croydon, England.

[19] Weisenburger DD. (1993). Human health effects of agrichemical use. Perspectives in Pathology, 24(6), 571-576.

[20] Margani M, Rossier D, Crettaz P and Jolliet O. (2002). Life cycle impact assessment of pesticides on human health and ecosystems. Agriculture, Ecosystems and Environmental, 379-392.

[21] Blair A, Ritz B, Wesseling C and Freeman LB. (2014). Pesticides and human health. Occupational and Environmental Medicine, 27(2), 1-8.

[22] Nicolopoulou-Stamati P, Maipas S, Stamatis P and Hens L. (2016). Chemical pesticides and human ealth: The urgent need for a new concept in agriculture. Front. Public Health, 1-28.

[23] Kom IARYD, Biesmeijer JC and Aquirre-Gutierrez J. (2019). Risk of potantial pesticide use to honeybee and bumblebee survival and distribution: A country-wide analysis for The Netherlands. Diversity and Distribution. 25 (11), 1709-1720.

[24] Craddock HA, Panthi S, Roub Y, Lipchin C, Sapkota A and Sapkota AR. (2020). Antibiotic and herbicide concentrations in household greywater reuse systems and pond water used for food crop irrigation: West Bank, Palestinian Territories. Science Of The Total Enviromental, 699, 134205.

[25] Mott L. (1992). Alar and Apples. Science 7(25), (5045) 665.

[26] Sanborn M, Kerr KJ, Sanin LH, Cole DC, Bassil KL and Vakil C. (2007). Non-cancer health effects of pesticides. Research, 53, 1714-1720.

[27] Singha Roy S, Begum M and Ghosh S. (2018). Exploration of teratogenic and genotoxic effects of fruit riperning retardant Alar (Daminozide) on model organism Drosophila Melanogaster. Interdisciplinary Toxicology, 11(1), 27-37. 
[28] Sagelsdorrf P, Lutz WK and Schlatter C. (1988). DNA Methylation in rat liver by daminozide 1, 1dimethylhydrazine and dimethylnitrozamine, Fundam. Appl. Toxicol, 11, 723-730.

[29] Linstromberg WW. (1989). Modern Organic Chemistry (Translated by Tahsin Uyar). Okan Publications, 86-176.

[30] Dere E, Bakır S and Aker A. (1995). Effect of daminozide on alkaline phosphatase activities in liver and kidney of male mice (Mus musculus. Cumhuriyet Medical Journal, 17(1), 6-10.

[31] Silig Y, Celik VK and Atalay A. (2000). Changen in liver cytoplasmic glutathione-s-transferase and microsomal nitrosodimethylamine demethylase activities in chicks obtained following daminozide treatment. Türk J. Biol. 2. 119-126.

[32] Gaulden ME. (1987). Hypothesis: some mutagens directly alter specific chromosomal proteins (DNA topoisomerases II and peripheral proteins) to produce chromosome stickiness, which causes chromosome aberrations. Mutagenesis, 2, 357-365.

[33] Rose RN, Woon ECY, Tumber A, Walport LJ, Chowdhury R, Li XS, King ONF, et. all. (2012). Plant growth regulator daminozide is a selective inhibitor of human KDM2/7 histone demethylase. Journal of Medicinal Chemistry. 55, 6639-6643.

[34] Zahm JDH, Hanberg A and Adami H. (1997). Pesticide and cancer. Cancer Causes and Control, 8, 420-443.

[35] Zeyad MT, Murugan K and Malik A. (2019). Mutagenicity, genotoxicity and oxidative stress induced by pesticide industry wastewater using bacterial and plant bioassays. Biotechnology Reports, In press, journal pre-proof, Available online 24 Article e00389.

\section{How to cite this article}

Dağ Ş and Dere E. (2020). In-vitro interaction of daminozide with some amino acids. World Journal of Advanced Research and Reviews, 5(1), 86-94. 